\title{
ANALYSIS OF M-P-F-A-A-C (MEANING - POSITIONING - FUNCTIONING - AUTHORIZING - ACTUATING - CONTROLLING) ON THE VILLAGE GOVERNMENT INSTITUTIONAL ARRANGEMENT (Law Making Philosophically of Law Number 6 of 2014 on Villages)
}

\author{
Sri Wahyu Kridasakti ${ }^{1}$; Sudarsono ${ }^{2}$; Chanif Nurcholis ${ }^{5}$ \\ 1,2,3 Universitas Terbuka
}

Email: sriwahyu@ecampus.ut.ac.id; sudarsono@ub.ac.id; hanif@ecampus.ut.ac.id

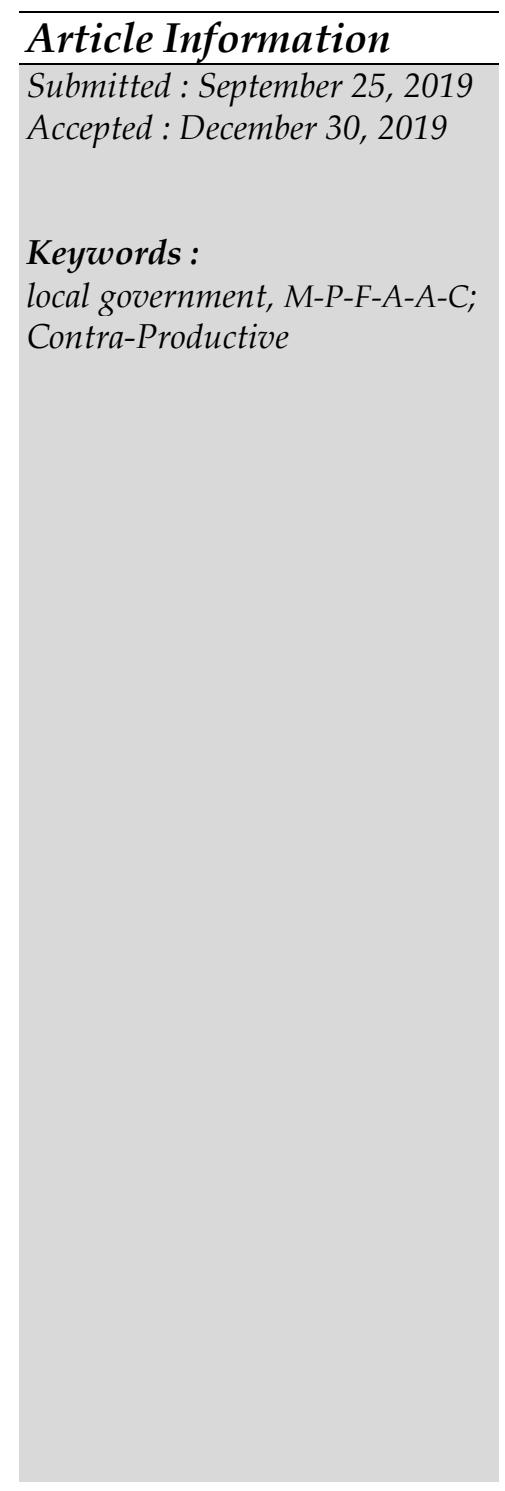

\begin{abstract}
The issue of the article is "What are the implications of village institutional governance for village governance institutional governance?". The legis ratio of Law Number 6 of 2014 states in Article 18 B paragraph (2) of the 1945 Constitution of the Republic of Indonesia, while the subject matters prescribed includes two main material types of different villages. This study uses a normative legal research method with a prescriptive conceptual approach and statute approach. The theoretical basis used is the rule of law, the theory of legislation, the concept of local government,; the concept of authority, and the concept of M-P-F$A-A-C$. The results showed that the village government regulated by Law Number 6 of 2014 is not an autonomous village but an independent village, not a customary law community unit and not a formal government. While the implications for governance in the Meaning aspect, happened to shift in the meaning of village government institutions from time to time; in the Positioning, the institutional status of village government as state-corporatism is a deviation in the administrative logic of local government; in the Functioning, the imposition of technocratic local government institutional function work is unrealistic to the institutional function of a self-governing community; in the Authorizing, authority over the principle of Recognition and Subsidiarity that is apparent from the government is outside the principle of decentralization; in the Actuating, the work apparatus of the village is not solid yet, showing poor regulation which also technocratic in Government Regulation Number 43 of 2014 Jo. Government Regulation Number 47 of 2015; in the Controlling, construction of checks $\mathcal{E}$ balances carried out by Village Council $(B P D)$ are still ineffective due to weak apparatus competence and low community participation in the policy making process. In conclusion, Law Number 6 of 2014 has a 'contra-productive' implication for village governance institutional governance, therefore Law Number 6 of 2014 needs to be reformulated.
\end{abstract}

\section{Introduction}

The status of the village administration regulated by Law Number 6 of 2014 on Villages raises legal issues in regional governance there is vertical harmonization with the norms of Article 18 B Paragraph (2) of the 1945 Constitution of The Republic of Indonesia it refers to. One of the main issues is regarding Law Number 6 of 2014 which

400 Yustisia Volume 8 Number 3 (Sept.-Dec. 2019)

Analysis of M-P-F-A-A-C...

C2019; This is an Open Acces Research distributed under the term of the Creative Commons Attribution Licencee (https://Creativecommons.org/licences/by/4.0), which permits unrestricted use, distribution, and reproduction in any medium, provided the original works is properly cited. 
regulates two main materials, namely on the Regular/Formal and Customary Villages, while Article 18 B paragraph (2) of the 1945 Constitution of The Republic of Indonesia stipulated recognition of the unity of indigenous peoples. Likewise, disharmony also occurs horizontally between Law Number 6 of 2014 and similar laws such as Law Number 5 of 2014 on State Civil Apparatus (ASN) related to the management and employment status of village officials as well as Law Number 17 of 2003 on State Finances regarding the limits of state financial management power which stop at the level of Regency/ City Government. In essence, disharmony caused by village governance institutional arrangements is not derived from a good governance system of village governance.

This study will raise the issue of harmonization of village governance institutional arrangements which concern on the impact of disharmony in village governance institutional arrangements for its institutional, analyzed with the M-P-F-A-A-C concept (Meaning - Positioning - Functioning - Authorizing - Acting - Controlling) (Sudarsono, 2019) .

The study conducted based on the urgency that no identification of institutional arrangements has made for village governance which happened to be contra-productive in the village. In other reason, there is no positive legis ratio enforcement of Law Number 6 of 2014, which raises new issues in sociological, juridical, and theoretical over the enactment. In addition, the old issue which discovers that the institutional arrangements of the village government are always placed outside the formal government system. Specifically, the background to the issue of village governance institutional arrangements may at least be described as follows.

The New Issue, for the 'Pro' is Law Number 6 of 2014 brought five phenomenal changes, namely the diversity of villages (Official Village_Customary Village), new principles for the Village Government (Recognition of Subsidiarity), Consolidation of Village Assets (Village Enterprise and others), Development Planning in Formal Local Government, Village Democratization (Direct election of village heads and the running of the Village Council in village governance). As for the 'Cons', the negative impact of the performance of the village government is since the village development found to be sluggish, low Village Funds Allocation (ADD) absorption capacity (Israwan S. P, 2011), increased regional corruption, long-pending banking budget.

The old problem is unidentified factor that causing problems in institutional governance of the village government always lead to disharmony in government administrative law.

The Philosophical problems stands on the undiscovered cause of the village government institutions shift from time to time. On the ontological issues, the definition and meaning of the village are always changing in line with the positive law enforcement of village laws from IGO-1906 to Law Number 6 of 2014. Therefore, the definition and meaning of the changing village governance institutions affect the functions and tasks that they carry out, and create vertical and horizontal disharmony, as well as with the constitution and other laws and regulations. On the epistemology issue, it is found that the village institutional government cannot run properly and optimally, while the status and function of the institution is still ambiguous 'Quasi Government' in the form of niet rechtstreek bestuured gabied governance model. On the axiology issue, a combination of local-self-government and self-governing community governance models imposed 
by the State will not be able to provide optimal benefits to the community, when the institutional system is inadequate in harmony with the constitution and legislation system, since its accountability system is not compatible with the regional government administration system.

The Sociological problem, it has not been found the impact of the contribution of the general mobilization of village empowerment assistance to the capacity of village officials' attenuation/strengthening.

The Theoretical Issues, the theoretical basis used to develop the institutional design of village governance remains inadequate and even appears chaotic in line with every positive law enforcement of village law. The theoretical basis used in the formation of Law Number 6 of 2014 is indicated not to be based on Local Government Theory, because the enactment of the village law is indeed outside the decentralized regime. In fact, the institutional status of village government is placed outside the local government system in the form of a combined model of local self-government and self-governing community which is niet rechstreek bestuured gabied (Indirect Government System). Until now, there has not been found an adequate theoretical basis that can explain the phenomenon of village governance institutional arrangements which are 'Quasi Government'.

The Juridical Issue, occurs in the form of 'Vertical' disharmony of the Law Number 6 of 2014 which regulates Customary Villages and Formal/Official Villages with Article 18 B paragraph (2) of the 1945 Constitution of the Republic of Indonesia which does not regulate Formal/Official Villages. In the 'Horizontal' disharmony with Law Number 5 of 2014 on ASN because village officials are not civil servants, ASN, or Labor/Workers according to Law Number 13 of 2003 on Manpower, as well as with Law Number 17 of 2003 on State Finances (which only regulates and limits financial management country stops until Regency/City level). Deviations from the principles of the formation of laws and regulations were also allegedly based on the principle of het beginsel van duidelijke doelstelling because of the ambiguity of the institutional objectives of the village government as a 'Quasi-Government' to be allegedly not optimal; Deviations from the principle of van het juiste organ begins due to the unclear model of the combined system of local government-self-government with self-governing community; Deviations on the principle of beginsel van het juiste organ, because it allegedly did not meet the practical element to be implemented through a combined model of local government system of self-government with self-governing community; Deviations on the principle of het beginsel van duidelijke terminologi en sistematiek, due to the positive arrangement of village government institutions outside the local government system; Deviations from the principle of het beginsel van de individuele rechtsbedeling, due to excessive workloads in the implementation of main duties and functions in the village apparatus above their skills and attitudes. Based on the foregoing issues, the question of the research could be narrowed into: why could the legal disharmony in village institutional arrangements occur?; ('What is the legal ratio of the institutional arrangements of the village government in the constitution and the law)?; what are the legal implications of the village governance institutions that are not in harmony with the village governance system? 


\section{Research Methods}

This study uses a normative legal research methodology with a prescriptive conceptual-approach and statute-approach approach to the object of village governance institutional arrangements analysis. Data collection techniques conducted through the study of legal materials (primary-secondary-tertiary) related to institutional arrangements in village governance, through the design of two clusters of legal material studies, among others: Cluster Study of Primary Legal Materials (normative reflection through organic laws and judicial decisions related to regulation on village law) and Secondary and Tertiary Legal Material Study (empirical reflection on village government institutional arrangements, including: academic texts on the Village Bill, literature, journal articles, e-news, newspapers, interview results, unpublished papers). The content analysis technique of legal materials uses the Statute Approach, which is a study of organic legal documents as primary legal materials related to the institutional status of village governance. Likewise, secondary legal materials were reviewed including academic texts, draft laws and various scientific articles in journals related to village government institutions, paper-work/study reports/legal-structure studies of village government institutions. The tertiary legal material in the form of a list of indexes Constitutional Court decision and legal dictionary used as a reference for verification and nomenclature related to village government institutions. While the theoretical basis used as a tool for analysis is outlined in the following matrix:

\section{MATRIC-1 THEORETICAL BASIS AND THE CONCEPT OF ANALYSIS ARRANGEMENTS OF VILLAGE GOVERNMENT INSTITUTIONS}

\begin{tabular}{|c|l|l|}
\hline No & \multicolumn{1}{|c|}{ Theory } & \multicolumn{1}{c|}{ Description of Application } \\
\hline 1 & Rule of Law Theory & $\begin{array}{l}\text { The problem is whether the people's sovereignty in the } \\
\text { positive enforcement of laws and regulations guarantee } \\
\text { to provide legitimacy to the laws and regulations that they } \\
\text { make (in the context of positive enforcement of village } \\
\text { law); Therefore, the theory of the rule of law is used to } \\
\text { examine the issue of the concept of popular sovereignty } \\
\text { in the positive application of Law Number 6 of 2014 in } \\
\text { providing legitimacy through legal considerations (ratio- } \\
\text { legis) of the laws and regulations it stipulates; }\end{array}$ \\
\hline 2 & $\begin{array}{l}\text { Legislative Theory } \\
\text { and Theory of Law } \\
\text { Political }\end{array}$ & $\begin{array}{l}\text { The problem is whether the principles in the formation } \\
\text { of laws and regulations can be negated by Law-Policy } \\
\text { in the context of village laws positive enforcement; } \\
\text { Therefore, the Legislative Theory and Political Theory } \\
\text { of Law are used to dissect and see whether or not the } \\
\text { fulfillment of the elements, criteria and principles in the } \\
\text { positive implementation of Law Number 6 of 2014 }\end{array}$ \\
\hline
\end{tabular}




\begin{tabular}{|c|c|c|}
\hline 3 & History of Law Theory & $\begin{array}{l}\text { The problem is whether the history of law as a } \\
\text { volksgeist can show the main causes of the problem on } \\
\text { institutional arrangements in the village administration, } \\
\text { which so far cannot be demonstrated by other means } \\
\text { through the law-policy process and the formation of } \\
\text { legislation. Therefore, the History of Law Theory is } \\
\text { used as an instrument to map the substance of the legal } \\
\text { political products of village government institutional } \\
\text { arrangements over time; The 'Theory of Political Law } \\
\text { is also used in uncovering the issue of whether the } \\
\text { politics of law only reflects the 'vested-interest' of the } \\
\text { ruling regime only or also considers the substantive } \\
\text { objectives that legitimate the harmonious legal relations } \\
\text { in the institutional arrangements of village government } \\
\text { from time to time. }\end{array}$ \\
\hline 4 & $\begin{array}{l}\text { The Concept of Local } \\
\text { Government }\end{array}$ & $\begin{array}{l}\text { The issue is whether the concept of regional government } \\
\text { system can decipher collectivism-pluralistic and } \\
\text { accommodate the polarization of localist-existencialism } \\
\text { and orientalist-modernism ideology in the institutional } \\
\text { arrangement of village government which is } \\
\text { 'autonomous' not 'Pseudo Government'. Therefore, the } \\
\text { concept of regional government is used to see whether } \\
\text { or not there are deviations from the principles which } \\
\text { may apply in the regional governance system in the } \\
\text { institutional arrangement of village government }\end{array}$ \\
\hline 5 & $\begin{array}{l}\text { The Concept of } \\
\text { Authority }\end{array}$ & $\begin{array}{l}\text { The problem is whether the attributive autho-rity given } \\
\text { to village government institutions through 'recognition } \\
\text { and subsidiarity' which is niet rechtstreek bestuured } \\
\text { gabied (Indirect Government) can be decomposed and } \\
\text { justified according to the theory of authority in the local } \\
\text { government system. Therefore, the Concept of Authority } \\
\text { is used as a logical foundation to examine how authority } \\
\text { is formed and delegated }\end{array}$ \\
\hline 6 & $\begin{array}{l}\text { The Concept of Legal } \\
\text { Harmony }\end{array}$ & $\begin{array}{l}\text { The problem is whether there is legal disharmony over } \\
\text { the positive implementation of Law Number } 6 \text { of } 2014 \\
\text { which can be shown vertically with the constitution or } \\
\text { horizontally with other laws. Therefore, the concept of } \\
\text { legal harmony is used as a basis for building framework } \\
\text { to show whether there is such disharmony }\end{array}$ \\
\hline 7 & $\begin{array}{l}\text { The Concept } \\
\text { of Institutional } \\
\text { Government }\end{array}$ & $\begin{array}{l}\text { The problem is whether the village government } \\
\text { institution created by the various Ordinary/Formal/ } \\
\text { Bureaucratic/Official and Customary Villages, together } \\
\text { with the changes in their status, can be parsed and } \\
\text { theoretically accommodated on the terms and criteria } \\
\text { of 'Community Government', 'Quasi Government' } \\
\text { to 'Actual Government'. Therefore, that the Concept } \\
\text { of Institutional Governance is used as a theoretical } \\
\text { justification to find the criteria for establishing local } \\
\text { government institutions and setting changes in their } \\
\text { status }\end{array}$ \\
\hline
\end{tabular}




\begin{tabular}{|c|c|c|}
\hline 8 & $\begin{array}{l}\text { The Concept of } \\
\text { MPFAAC. }\end{array}$ & $\begin{array}{l}\text { The problem is whether the MPFAAC analytical } \\
\text { framework can be used as an adequate guide-line } \\
\text { analysis to dissect the institutional arrangements of } \\
\text { village governance. Therefore, the MPFAAC concept is } \\
\text { utilized as a rigid and complete step-by-step guide-line } \\
\text { analysis to obtain a full picture of the problems with the } \\
\text { institutional arrangements of village governance. }\end{array}$ \\
\hline 9 & $\begin{array}{l}\text { The Concept of } \\
\text { Arrangement }\end{array}$ & $\begin{array}{l}\text { The nomenclature "Arrangement" chosen is used } \\
\text { to represent a line of thought that means that the } \\
\text { 'Arrangement' of the basic word 'govern' is as a } \\
\text { regeling in the institutional issue of village governance, } \\
\text { as is commonly used in the theory of government } \\
\text { administration. }\end{array}$ \\
\hline 10 & $\begin{array}{l}\text { The Concept of } \\
\text { Institutional }\end{array}$ & $\begin{array}{l}\text { Institutions are generally more meaningful to } \\
\text { organizations, institutions or body, which means the rules } \\
\text { in organizations or community groups to help members } \\
\text { to interact with one another to achieve the desired goals } \\
\text { (Pusat Bahasa Kemdikbud, 2016) }\end{array}$ \\
\hline 11 & $\begin{array}{l}\text { The Concept of } \\
\text { Government }\end{array}$ & $\begin{array}{l}\text { In the nomenclature of "government", what is meant } \\
\text { by (without the capital letter "g") is government in } \\
\text { a broad sense that is all the activities of public bodies } \\
\text { both legislative, executive and judiciary in an effort to } \\
\text { achieve the goals of the state; while 'government' in the } \\
\text { narrow sense is all activities of public bodies which only } \\
\text { include executive power (Strong C. F, 2015) }\end{array}$ \\
\hline 12 & The Concept of Village & $\begin{array}{l}\text { The term 'village' comes from the Sanskrit 'dhesi' which } \\
\text { is 'land of birth', then becomes 'Swadesi' which means } \\
\text { a place of residence, country of origin, or ancestral land } \\
\text { that refers to a single unit of life, with one unitary norm, } \\
\text { and has clear boundaries (Soetardjo Kartohadikoesoemo, } \\
\text { 1984) }\end{array}$ \\
\hline 13 & $\begin{array}{l}\text { The Concept of } \\
\text { Meaning }\end{array}$ & $\begin{array}{l}\text { The definition/meaning/n is: the intention of the } \\
\text { speaker or writer; or understanding given to a form of } \\
\text { language; meaningful } \bullet \text { meaning } \bullet \text { na / v; has (contains) } \\
\text { important meaning (in): the sentence is - multiple; - is } \\
\text { said to have (contains) several meanings; (Pusat Bahasa } \\
\text { Kemdikbud, 2016) Examining the nature of institutional } \\
\text { meaning of village governance from the perspective of } \\
\text { the philosophy of science and legal theory bears two } \\
\text { meanings, namely as a place and as a functie (function) } \\
\text { (Pusat Bahasa Kemdikbud, 2016) }\end{array}$ \\
\hline 14 & $\begin{array}{l}\text { The Concept of } \\
\text { Positioning }\end{array}$ & $\begin{array}{l}\text { Positioning as English is defined in Indonesian as } \\
\text { regulating the place or position of something (Pusat } \\
\text { Bahasa Kemdikbud, 2016) }\end{array}$ \\
\hline
\end{tabular}




\begin{tabular}{|c|c|c|}
\hline 15 & $\begin{array}{l}\text { The Concept of } \\
\text { Functioning }\end{array}$ & $\begin{array}{l}\text { Functioning is derived from English which in Indonesian } \\
\text { means Function, while the vocabulary of the Function in } \\
\text { this case according to the Big Indonesian Dictionary is } \\
\text { interpreted as the usefulness of a matter (Pusat Bahasa } \\
\text { Kemdikbud, 2016). }\end{array}$ \\
\hline 16 & $\begin{array}{l}\text { The Concept of } \\
\text { Authorizing }\end{array}$ & $\begin{array}{l}\text { Authorizing derived from English is interpreted in In- } \\
\text { donesian as an authority to permit, authorize, approve, } \\
\text { grant rights, or justify (Carr, Echols, \& Shadily, 1977) } \\
\text { More specifically 'authority' is defined as the right or } \\
\text { power to give orders or act to influence the actions of } \\
\text { others. Therefore, something is done as desired (Team, } \\
\text { 1989) }\end{array}$ \\
\hline 17 & $\begin{array}{l}\text { The concept of } \\
\text { Actuating }\end{array}$ & $\begin{array}{l}\text { The meaning of actuate comes from English which in } \\
\text { letterlijk is "to move to action" which is to move people } \\
\text { to move, which is interpreted in Indonesian as moving or } \\
\text { running something (Carr et al., 1977) Doing something } \\
\text { means doing or carrying out tasks, obligations, work } \\
\text { (Pusat Bahasa Kemdikbud, 2016) According to } \\
\text { Sudarsono, the concept of Actuating includes the sub- } \\
\text { concepts of Tasking and Activating (Pusat Bahasa } \\
\text { Kemdikbud, 2016). }\end{array}$ \\
\hline 18 & $\begin{array}{l}\text { The Concept of } \\
\text { Controlling }\end{array}$ & $\begin{array}{l}\text { The concept of Controlling in English is more defined } \\
\text { as controlling (controlling) rather than supervising } \\
\text { (supervising) (Carr et al., 1977) In the legal context, } \\
\text { control is basically directed entirely to avoidthe possibility } \\
\text { of diversion or deviation from the implementation of } \\
\text { legislation for the purpose to be achieved. }\end{array}$ \\
\hline
\end{tabular}

To answer the question of the research questions, this study has traced the legalhistory of village government institutions since IS-1837, RR-1854 No. 16, IGO-1906, IGOB1938, Osamu Seirei No. 27 of 1942, Osamu Seirei No. 7 of 1944, Law Number 22 of 1948, Law Number 1of 1957, Law Number 19 of 1965, Law Number 5 of 1979, Law Number 22 of 1999, Law Number 32 of 2004, and Law Number 6 of 2014.(Roper \& Friedman, 1976) Based on the construction of the legal-history, a Legal-Structure evaluation of the village government institution status up to the Legal-Substance norm which regulated under Law Number 6 of 2014. The final result of this study is in the form of the legality profile and legitimacy of the institutional status of the village administration in the context of vertical synchronicity with Article 18 B paragraph (2) of the 1945 Constitution of the Republic of Indonesia and horizontally with Article 1 of RI Law Number 5 of 2014 on ASN and with Article 6 paragraph (2) letter c of Law Number 17 of 2003 concerning State Finances. The basic concept that has been used as an instrument for analyzing the status of village government institutions based on Law Number 6 of 2014 which covers the concepts of Legality and Legitimacy; (Dyzenhaus, 2012) Regional Autonomy Theory; (Hoessein, 2011) Theory of Authority;(Hadjon P. M, 2005) and Legislative Theory. (Hadjon P. M, 2005) 


\section{Research Result And Discussion}

A. Legal Disharmony is Due to The Institutional Arrangements of The Village Administration Based Results of Analysis on The Causes of Legis Disharmonic and Ratio Legis on Law Number 6 of 2014

In general, the results of the study indicate that the cause of the vertical and horizontal legal disharmony is due to the institutional arrangements of the village administration (both Customary/Ordinary/Official/Formal/Bureaucracy Village) whicharenotderived from the provisions of a good (legal) and good governancesystem legitimate). The legal considerations of the various village governance institutional arrangements are based on historical facts that the Ordinary/Bureaucracy/Formal/ Official and the indigenous community unit that are dominant in the territorial area of the village have become practices of village daily life (contitutional court, 2015) Therefore, the attributive determination of the institutional authority of the village government based on the principles of recognition and subsidiarity outside the local government system (niet rechstreek bestuured gabied), causes disharmony with other laws and regulations. The manifestation of supra-village recognition and respect for the customary law community unit (Article $8 \mathrm{~B}$ paragraph (2) of the 1945 Constitution of the Republic of Indonesia) in the village territorial place called Customary Village is a legal consideration in the various institutional arrangements for the village administration. But even the norm of Article $8 \mathrm{~B}$ paragraph (2) of the 1945 Constitution of the Republic of Indonesia which was referred to Law Number 6 of 2014 in the institutional arrangement of this village government became irrelevant and incited vertical disharmony. This is due to the affirmation of the birth of the institutional authority of the village government that is outside the "womb of decentralization" of local government.n The the general results of the analysis on the causes of disharmony and legis ratios of village governance institutional arrangements:

MATRIC-2 GENERAL RESULTS OF ANALYSIS ON THE CAUSES OF LEGIS DISHARMONIC AND RATIO LEGIS ON LAW NUMBER 6 OF 2014

\begin{tabular}{|c|c|c|}
\hline & CAUSE OF DISHARMONY & $\begin{array}{l}\text { RATIO LEGIS LAW NUMBER } 6 \text { OF } \\
\qquad 2014\end{array}$ \\
\hline & $\begin{array}{l}\text { The cause of legal disharmony is } \\
\text { due to the institutional arrangement } \\
\text { of the village administration is } \\
\text { not derived from the right and } \\
\text { legitimate provisions of the legal } \\
\text { system (Article } 18 \text { paragraph (7) } \\
\text { of the } 1945 \text { Constitution of the } \\
\text { Republic of Indonesia. }\end{array}$ & $\begin{array}{l}\S \text { The spirit of the mandate of Article } 18 \mathrm{~B} \\
\text { paragraph (1), paragraph (2) \& paragraph } \\
\text { (7) of the } 1945 \text { Constitution of the } \\
\text { Republic of Indonesia even though it does } \\
\text { not regulate the village. } \\
\S \text { Based on historical facts that the Ordinary } \\
\text { Village and the indigenous community } \\
\text { unity are in the territory of the village } \\
\text { which has become the daily practice of } \\
\text { the village (Decision of the Constitutional } \\
\text { Court Number } 128 / \text { PUU-XIII/2015). }\end{array}$ \\
\hline
\end{tabular}

Yustisia Volume 8 Number 3 (Sept.-Dec. 2019)

Analysis of M-P-F-A-A-C... 


\begin{tabular}{|c|c|c|}
\hline & $\begin{array}{l}\text { Article } 18 \text { B paragraph (2) of } \\
\text { the } 1945 \text { Constitution of the } \\
\text { Republic of Indonesia referred to } \\
\text { Law Number } 6 \text { of } 2014 \text { does not } \\
\text { regulate villages and therefore } \\
\text { the institutional arrangements for } \\
\text { village governance are irrelevant } \\
\text { and involve vertical disharmony. }\end{array}$ & $\begin{array}{l}\S \text { Supra-village recognition and respect for } \\
\text { the indigenous community unit (Article } 18 \\
\text { B paragraph (2) of the } 1945 \text { Constitution } \\
\text { of the Republic of Indonesia) in the village } \\
\text { territorial place, namely Customary } \\
\text { Village, is a legal consideration in the } \\
\text { various institutional arrangements for } \\
\text { village governance. }\end{array}$ \\
\hline$\S$ & $\begin{array}{l}\text { There was a polarization of } \\
\text { philosophical ideas in the } \\
\text { institutional arrangements of the } \\
\text { village administration, the Local } \\
\text { Existentialism and Modernist } \\
\text { Orientalism. Local Existentialist } \\
\text { ideology won the law-policy for } \\
\text { the positive implementation of } \\
\text { Law Number 1 of } 2014 \text { (Evaluation } \\
\text { Results of Regional Representative } \\
\text { Council, 2017). }\end{array}$ & $\begin{array}{l}\text { Attributive determination of ins-titutiona } \\
\text { village government authority based on the } \\
\text { principle of recognition and subsidiarity } \\
\text { (Article } 3 \text { of Law Number } 6 \text { of 2014) is } \\
\text { outside the local government system (nie } \\
\text { rechstreek bestuured gabied), causing } \\
\text { disharmony in statutory regulations } \\
\text { The existence of institutional Village } \\
\text { governance authority is outside the "womb } \\
\text { of decentralization" of local govern-ment. }\end{array}$ \\
\hline
\end{tabular}

In the independence era of the Republic of Indonesia, especially in the Reform Order, there was a polarization of philosophical ideas in the institutional arrangements of the village administration, namely the Localist Existentialist and Modernist Orientalist ideologies. Although the Localist Existentialist ideology won the law-policy for the positive implementation of Law Number 6 of 2014. The Matrix concerning the ideology of institutional arrangements in village governance is presented as follows:

\section{MATRIX-3 IDEOLOGY IN THE INSTITUTIONAL ARRANGEMENT OF VILLAGE GOVERNMENT}

\begin{tabular}{|c|c|c|c|c|}
\hline Variable & $\begin{array}{c}\text { Localist } \\
\text { Existentialist }\end{array}$ & $\begin{array}{l}\text { Modernist } \\
\text { Orientalist }\end{array}$ & $\begin{array}{l}\text { Structuralist- } \\
\text { Radicalist }\end{array}$ & $\begin{array}{c}\text { Existentialist- } \\
\text { Modernist (Mixed) }\end{array}$ \\
\hline $\begin{array}{l}\text { Basic } \\
\text { Argument }\end{array}$ & $\begin{array}{l}\text { The village is } \\
\text { the site of } \\
\text { authenticity } \\
\text { and the basis } \\
\text { of modern } \\
\text { nation of state } \\
\text { civilization }\end{array}$ & $\begin{array}{l}\text { The village is a } \\
\text { site of ignorance, } \\
\text { s t a g n a t i o n, } \\
\text { poverty, under } \\
\text { development }\end{array}$ & $\begin{array}{l}\text { The village is } \\
\text { a site of in- } \\
\text { e qua } 1 \mathrm{it} y \text {, } \\
\text { oppression, } \\
\text { elite exploi- } \\
\text { tation of the } \\
\text { proletariat }\end{array}$ & $\begin{array}{l}\text { The village is a site of } \\
\text { authenticity and the ba- } \\
\text { sis of modern nation } \\
\text { state civilization as well } \\
\text { as a site of poverty and } \\
\text { underdevelopment }\end{array}$ \\
\hline $\begin{array}{l}\text { Views on } \\
\text { Village } \\
\text { D e m o- } \\
\text { cracy }\end{array}$ & $\begin{array}{l}\text { Communitari- } \\
\text { an democracy } \\
\text { (common good } \\
\text { and delibera- } \\
\text { tion) }\end{array}$ & $\begin{array}{l}\text { Liberal democ- } \\
\text { racy (individual } \\
\text { freedom and re- } \\
\text { presentative de- } \\
\text { mocracy) }\end{array}$ & $\begin{array}{l}\text { Radical demo- } \\
\text { cracy (strong } \\
\text { people's } \\
\text { organizations } \\
\text { toseize power) }\end{array}$ & $\begin{array}{l}\text { C o m m u n i t a r i a n } \\
\text { democracy (the common } \\
\text { good and deliberation) as } \\
\text { well as liberal democracy }\end{array}$ \\
\hline
\end{tabular}




\begin{tabular}{|l|l|l|l|l|}
\hline $\begin{array}{l}\text { Key } \\
\text { Concepts }\end{array}$ & $\begin{array}{l}\text { Independence, } \\
\text { togetheness, } \\
\text { mutual coope- } \\
\text { ration, solidarity }\end{array}$ & $\begin{array}{l}\text { Freedom, open- } \\
\text { ness, participation, } \\
\text { etc. }\end{array}$ & $\begin{array}{l}\text { Sovereignty } \\
\text { of the people, } \\
\text { liber ation, } \\
\text { justice }\end{array}$ & $\begin{array}{l}\text { Independence, together- } \\
\text { ness, mutual coopera- } \\
\text { tion, solidarity as well as } \\
\text { freedom, openness, par- } \\
\text { ticipation. }\end{array}$ \\
\hline $\begin{array}{l}\text { Change of } \\
\text { Platform }\end{array}$ & $\begin{array}{l}\text { Restorative } \\
\text { of Village } \\
\text { Republic }\end{array}$ & $\begin{array}{l}\text { Modernization, } \\
\text { Economic } \\
\text { Growth }\end{array}$ & $\begin{array}{l}\text { Educate and } \\
\text { organize the } \\
\text { people, land } \\
\text { reform. }\end{array}$ & $\begin{array}{l}\text { Restoration of the village } \\
\text { republic as } \\
\text { well as Modernization, } \\
\text { economic growth. }\end{array}$ \\
\hline
\end{tabular}

Source: The committee of Regional Representative Council. 2017. Return to Mandate Results of the Supervision of the Regional Representative Council on the Implementation of Law Number 6 of 2014 concerning Villages. Regional Representative Council Committee I. added to the Existentialist view with Modernists by Rikardo Simarmata, interview on October 29, 2018.

\section{Analysis Of Historical Perspective On Institutional Arrangements Of Village Governments As The Impact Of The Disharmonicity Of Legislation}

Whereas the results of MPFAAC's analysis of the disharmony implications of village governance institutional arrangements from the perspective of time are shown as follows:

\section{MATRIX-4 RESULTS OF MPFC ANALYSIS OF HISTORICAL PERSPECTIVE ON INSTITUTIONAL ARRANGEMENTS OF VILLAGE GOVERNMENTS AS THE IMPACT OF THE DISHARMONICITY OF LEGISLATION}

\begin{tabular}{|c|c|c|c|c|c|}
\hline \multirow{2}{*}{$\begin{array}{c}\text { SUB- } \\
\text { STANCE }\end{array}$} & DUTCH & JAPAN & OLD ORDER & NEW ORDER & REFORM ORDER \\
\hline & $\begin{array}{l}\text { IGO 1906/ } \\
\text { IGOB-1938 }\end{array}$ & $\begin{array}{c}\text { OSAMU-SEIREI } \\
\text { No. } 7 \text { Syoowa } 19 \\
(1944)\end{array}$ & $\begin{array}{c}\text { LAW NUMBER } 19 \text { OF } \\
1965\end{array}$ & $\begin{array}{l}\text { LAW NUMBER } 7 \\
\text { OF } 1979\end{array}$ & LAW NUMBER 6 OF 2014 \\
\hline $\begin{array}{l}\text { Mean- } \\
\text { ing }\end{array}$ & $\begin{array}{l}\text { - State Corpo- } \\
\text { ratism }\end{array}$ & $\begin{array}{l}\text { Position_-State } \\
\text { Corporatism }\end{array}$ & $\begin{array}{l}\text { Position_Local-Self } \\
\text { Government } \\
\text { Autonomous Village } \\
\text { in the meaning of } \\
\text { authority under the } \\
\text { principle of 'Recogni- } \\
\text { tion and Subsidiarity' } \\
\text { according to the legal } \\
\text { system regime of the } \\
\text { regional government } \\
\text { under the principle } \\
\text { of decentralization } \\
\text { (Article-34 and Expla- } \\
\text { nation of Law Number } \\
19 \text { of 1965) }\end{array}$ & $\begin{array}{l}\text { Position_State } \\
\text { Corporatism } \\
\text { Autonomous } \\
\text { Village in the } \\
\text { meaning of } \\
\text { attributive } \\
\text { authority } \\
\text { (Chapter-1 } \\
\text { Article-1 letter } \\
\text { (a) of Law } \\
\text { Number } 5 \text { of } \\
\text { 1979) }\end{array}$ & $\begin{array}{l}\text { Position of Local-Self Govt. and } \\
\text { Self-Governing Community in the } \\
\text { format of State Corporation. } \\
\text { Autonomous Village inthe } \\
\text { meaning of authority under the } \\
\text { principle of 'Recognition and } \\
\text { Subsidiarity' (Article } 1 \text { number } \\
6 \text { of Law Number } 3 \text { of } 2004 \text { and } \\
\text { Chapter-I General Provisions } \\
\text { Article } 1 \text { paragraph (1) and } \\
\text { paragraph (2) of Law Number } 6 \\
\text { of 2014). } \\
\text { However, the empirical principle } \\
\text { of recognition and subsidiarity } \\
\text { does not apply. }\end{array}$ \\
\hline & $\begin{array}{l}\text { The } \\
\text { Democracy } \\
\text { System_The } \\
\text { head of } \\
\text { the village } \\
\text { is directly } \\
\text { elected by the } \\
\text { Villagers. }\end{array}$ & $\begin{array}{l}\text { The Democracy } \\
\text { System The head } \\
\text { of the village is } \\
\text { directly elected by } \\
\text { the Villagers. }\end{array}$ & $\begin{array}{l}\text { The Democracy } \\
\text { System_The head } \\
\text { of the village is } \\
\text { directly elected by the } \\
\text { Villagers. }\end{array}$ & $\begin{array}{l}\text { The Democracy } \\
\text { Head of village } \\
\text { is directly } \\
\text { chosen by the } \\
\text { Villagers. } \\
\text { o Village Con- } \\
\text { sultative Body } \\
\text { (LMD) Members } \\
\text { are not directly } \\
\text { elected by the } \\
\text { people. } \\
\text { o Village Con- } \\
\text { sultative Body } \\
\text { Chairperson } \\
\text { and Secretary } \\
\text { are ex-officio } \\
\text { Head of Village } \\
\text { and Secretary of } \\
\text { Village. }\end{array}$ & $\begin{array}{l}\text { The Democracy System_The } \\
\text { Head of the Village is chosen } \\
\text { directly by the Villagers. } \\
\text { Democratic System_BPD Mem- } \\
\text { bers are not directly elected by the } \\
\text { community. }\end{array}$ \\
\hline
\end{tabular}




\begin{tabular}{|c|c|c|c|c|c|}
\hline $\begin{array}{l}\text { Posi- } \\
\text { tioning }\end{array}$ & $\begin{array}{l}\text { Government } \\
\text { Model - Quasi } \\
\text { Government }\end{array}$ & $\begin{array}{l}\text { Government } \\
\text { Model - Quasi } \\
\text { Government }\end{array}$ & $\begin{array}{l}\text { De Jure's Government } \\
\text { Model is a Formal } \\
\text { Government (never im- } \\
\text { plemented), De Facto is } \\
\text { Pseudo Government. }\end{array}$ & $\begin{array}{l}\text { Government } \\
\text { Model - Quasi } \\
\text { Government }\end{array}$ & $\begin{array}{l}\text { Government Model - Quasi } \\
\text { Government }\end{array}$ \\
\hline & $\begin{array}{l}\text { Definition of } \\
\text { "Inlandsche } \\
\text { Gemeente": } \\
\text { Village } \\
\text { Hoofd" }\end{array}$ & $\begin{array}{l}\text { o Definition of } \\
\text { "Village Govern- } \\
\text { ment / KU": } \\
\text { "Kutyoo / Village } \\
\text { Head" }\end{array}$ & $\begin{array}{l}\text { Definition of "Village } \\
\text { Government" Head } \\
\text { of the Praja village } \\
\text { - Village Council } \\
\text { Consultative Body. }\end{array}$ & $\begin{array}{l}\text { Definition } \\
\text { of "Village } \\
\text { Government" } \\
\text { - Village Head - } \\
\text { LMD }\end{array}$ & $\begin{array}{l}\text { Definition of "village govern- } \\
\text { ment"_Head of the village or } \\
\text { referred to by another name and } \\
\text { Village Apparatus. } \\
\text { Definition of "village govern- } \\
\text { ment"_consists of village } \\
\text { government \& BPD }\end{array}$ \\
\hline \multirow[t]{2}{*}{$\begin{array}{l}\text { O Func- } \\
\text { tioning }\end{array}$} & $\begin{array}{l}\text { Responsible } \\
\text { to Onder } \\
\text { District/ } \\
\text { aOrchard }\end{array}$ & $\begin{array}{l}\text { Responsible to } \\
\text { Guntyoo (Head of } \\
\text { Sub-district) }\end{array}$ & $\circ$ Responsible to BMD & $\begin{array}{l}\text { Responsible } \\
\text { to the Head of } \\
\text { Sub-district }\end{array}$ & $\begin{array}{l}\text { Responsible to the Regent/Mayor } \\
\text { (Head of Sub-district) \& BMD }\end{array}$ \\
\hline & $\begin{array}{l}\text { Term of } \\
\text { Office_- Year }\end{array}$ & $\begin{array}{l}\text { O Term of Office_4 } \\
\text { Years }\end{array}$ & $\begin{array}{l}\text { Term of Office_ } 8 \\
\text { Years }\end{array}$ & $\begin{array}{l}\text { Term of Office } \\
8 \text { Years }\end{array}$ & ○ Term of Office_6 Years \\
\hline $\begin{array}{l}\text { Actuat- } \\
\text { ing }\end{array}$ & $\begin{array}{l}\text { Governance } \\
\text { Character- } \\
\text { Quasy/Pseudo } \\
\text { Goverment }\end{array}$ & $\begin{array}{l}\text { O Governance } \\
\text { Character_Quasy/ } \\
\text { Pseudo Goverment }\end{array}$ & $\begin{array}{l}\text { Governance Character } \\
\text { Quasy/Pseudo } \\
\text { Goverment }\end{array}$ & $\begin{array}{l}\text { Governance } \\
\text { Character } \\
\text { Quasy/Pseudo } \\
\text { Goverment }\end{array}$ & $\begin{array}{l}\text { Governance Character_Quasy/ } \\
\text { Pseudo Goverment }\end{array}$ \\
\hline \multirow[t]{2}{*}{$\begin{array}{l}\text { Autho- } \\
\text { rizing }\end{array}$} & $\begin{array}{l}\text { Legal Product } \\
\text { The Village } \\
\text { Decree is } \\
\text { governed by } \\
\text { a Regional } \\
\text { Regulation } \\
\text { which is } \\
\text { approved by } \\
\text { the authorized } \\
\text { official. }\end{array}$ & $\begin{array}{l}\text { Legal Product } \\
\text { The Village } \\
\text { Decree is } \\
\text { governed by } \\
\text { a Regional } \\
\text { Regulation which } \\
\text { is approved by } \\
\text { the authorized } \\
\text { official.. }\end{array}$ & $\begin{array}{l}\text { Legal Products } \\
\text { Village regulations } \\
\text { which do not require } \\
\text { authorization of } \\
\text { authorized officials. } \\
\text { The guideline is a } \\
\text { regional regulation } \\
\text { that does not } \\
\text { require the approval } \\
\text { of government } \\
\text { authorities. }\end{array}$ & $\begin{array}{l}\text { O Legal Product } \\
\text { The Village } \\
\text { Decree is } \\
\text { governed by a } \\
\text { Regional Regu- } \\
\text { lation which } \\
\text { is approved by } \\
\text { the authorized } \\
\text { official.. }\end{array}$ & $\begin{array}{l}\text { Legal Products_Village regulations } \\
\text { which do not require authorization } \\
\text { of authorized officials. The guideline } \\
\text { is a regional regulation that does not } \\
\text { require the approval of government } \\
\text { authorities. }\end{array}$ \\
\hline & $\begin{array}{l}\text { Character: } \\
\text { Inlandsche } \\
\text { Gemeente } \\
\text { Ordonnantie } \\
1906\end{array}$ & $\begin{array}{l}\text { Character: IGO } \\
1906 \text { jo. Osame } \\
\text { Seirei Number } \\
27 / 1942\end{array}$ & $\begin{array}{l}\text { O Character: Law Num- } \\
\text { ber } 19 \text { of } 1965 \text { on Praja } \\
\text { Village }\end{array}$ & $\begin{array}{l}\text { Character: Law } \\
\text { Number } 5 \text { of } \\
1975 \text { _Village } \\
\text { Government }\end{array}$ & $\begin{array}{l}\text { Character: Law Number } 22 \text { of } \\
1999 \text { was amended with Law } \\
\text { Number } 32 \text { of } 2004 \text { amended by } \\
\text { Law Number } 6 \text { of } 2014 \text {-Desa. }\end{array}$ \\
\hline $\begin{array}{l}\text { Con- } \\
\text { trolling }\end{array}$ & $\begin{array}{l}\text { Character: } \\
\text { "Directly } \\
\text { under the } \\
\text { control of cen- } \\
\text { tral officials } \\
\text { (onderdistrict } \\
\text { hoofd)" }\end{array}$ & $\begin{array}{l}\text { Character: } \\
\text { "Directly under } \\
\text { the control of } \\
\text { central officials } \\
\text { (Sontyoo)" }\end{array}$ & $\begin{array}{l}\text { Character 'Check- } \\
\text { Balances'_Village } \\
\text { Government with } \\
\text { BMD }\end{array}$ & $\begin{array}{l}\text { Character: } \\
\text { "Directly under } \\
\text { the control of } \\
\text { central officials } \\
\text { (Camat)" }\end{array}$ & $\begin{array}{l}\text { O Character 'Check-Balances' } \\
\text { Village Government with BMD }\end{array}$ \\
\hline
\end{tabular}

2. Analysis (Meaning - Positioning - Functioning - Authorizing - Actuating Controlling) on The Village Government Institutional Arrangement

The description of MPFAAC analysis from Matrix-4 above is as follows:

a. Meaning:

There has been a shift in the definition and meaning of village government institutions from time to time, which has implications for the village governance system. Since the promulgation of IGO-1906 until Law Number 6 of 2014, there has been a shift in the meaning of village government institutions which has implications for the authority. However, the shift in meaning does not occur in the realm of meaning of local government. The shift in the meaning of the village was shown through from a village just a community (Inlandsche-gemeenten _ RR-1854), becoming a rechtpersoon/rechgemeenschap/state corporation (IGO-1906 Jo. Osamu Seirei Number 27 of 1942), then the village was changed back to local self- formal government (Small Town or Level III) in the local government system (Law Number 22 of 1948 Jo. Law Number 1 of 1957 Jo. Law Number 18 of 1965 Jo. Law Number 19 of 1965), then the village government institutions were 
changed back to rechtpersoon/rechgemeenschap/state corporation in the form based on of IGO 1906 back (Law Number 5 of 1979 Jo.Law Number 22 of 1999 Jo.Law Number 32 of 2004 Jo. Law Number 6 of 2014). The institutional arrangement of the village administration is not followed by a shift in the status of the village as a full formal government, further causes the village government institutions to struggle on their own to resolve systemic and structural problems that create ineffectiveness and inefficiency of the village government in carrying out its main tasks and functions.

This pseudo form of governance of village government institutions is referred to as state-corporatism. The institutional arrangement of the village administration should refer to the formal governance system whose foundation is regulated in Article 18 paragraph (1), Article 18 paragraph (7), Article 18 A paragraph (1), and Article 18 B paragraph (1) of the 1945 Constitution of the Republic of Indonesia. However, the LawMakers through their legal politics formulate and enact Law Number 6 of 2014 referring to Article 18 B paragraph (2) of the 1945 Constitution of the Republic of Indonesia which regulates the customary law community unit (Kukuh Tejomurti, 2018: 272), even though the village government regulated in Article 1-95 is not customary law community unit (adat rechtgemeenschap) as referred to by van Vollenhoven (1907) (Veen, 1993) and Customary Villages regulated in Article 96-111 which also "does not recognize and respect" customary law community units as mandated by Article 18B paragraph (2) of the 1945 Constitution of the Republic of Indonesia in the sense of bureaucratization of village government institutions. The 1945 Constitution of the Republic of Indonesia does not at all regulate ordinary/ formal / official villages or customary villages. Therefore, the village law shall regulate two main materials about the village, namely the ordinary village and the customary village, the ratio-legis must refer to the articles contained in the 1945 Constitution of the Republic of Indonesia mentioned above. Here follows a shift in the meaning and institutional meaning of village governance from a historical perspective.

\section{MATRIC-5: SHIFTING ARTI - MEANING INSTITUTIONAL INSTITUTIONAL GOVERNMENTS OF TIME VILLAGE TO IMPLEMENTING TIME IN VILLAGE GOVERNMENT GOVERNANCE SYSTEMS}

\begin{tabular}{|c|c|c|c|c|c|}
\hline $\begin{array}{l}\text { Shift of } \\
\text { mean }\end{array}$ & $\begin{array}{c}\text { Dutch Colonial } \\
\text { Government }\end{array}$ & $\begin{array}{c}\text { Japan Colonial } \\
\text { Government }\end{array}$ & $\begin{array}{l}\text { Old Reform } \\
\text { Government }\end{array}$ & $\begin{array}{l}\text { New Order } \\
\text { Government }\end{array}$ & $\begin{array}{c}\text { Reform Order } \\
\text { Government }\end{array}$ \\
\hline Definition & $\begin{array}{l}\omega \text { The unit for Native } \\
\text { People Community } \\
\text { (RR-1834) } \\
\omega \text { Legal Community enti- } \\
\text { ty (rechtgemeenschap) } \\
\text { formed by the State } \\
\text { (state corporatism) } \\
\text { (IGO-1906 - IGOB- } \\
\text { 1938). }\end{array}$ & $\begin{array}{l}\omega \text { Legal Unit of } \\
\text { Native People } \\
\text { (Osamu Seirei No. } \\
27 \text { Syoowa } 19- \\
\text { 1942). }\end{array}$ & $\begin{array}{l}\text { कL Local Govern- } \\
\text { ment Autonomy } \\
\text { (local self-gov- } \\
\text { ernment) in the } \\
\text { formal local gov- } \\
\text { ernment (Law } \\
\text { Number 22 of } \\
\text { 1948, Law Num- } \\
\text { ber 1 of 1957, } \\
\text { Law Number 18 } \\
\text { of 1965, Law } \\
\text { Number19 of } \\
\text { 1965). }\end{array}$ & $\begin{array}{l}\omega \text { Legal Entity } \\
\text { (rechtgemeensc- } \\
\text { hap) formed by } \\
\text { State (state cor- } \\
\text { poratism) (Law } \\
\text { Number } 5 \text { of } \\
\text { 1979). }\end{array}$ & $\begin{array}{l}\omega \text { Community of Legal Entity } \\
\text { (rechtgemeenschap) formed } \\
\text { by State (state corporatism) } \\
\text { (Law Number } 22 \text { of 1999, } \\
\text { Law Number } 32 \text { of 2004, Law } \\
\text { Number } 6 \text { of 2014). }\end{array}$ \\
\hline
\end{tabular}




\begin{tabular}{|c|c|c|c|c|c|}
\hline Meaning & $\begin{array}{l}\omega \text { The place for territorial } \\
\text { area where indigenous } \\
\text { people live together. } \\
\omega \text { The place of legal } \\
\text { subjects of rural com- } \\
\text { munity with territorial } \\
\text { boundaries. } \\
\omega \text { The place of colonial } \\
\text { government tax ob- } \\
\text { jects. } \\
\omega \text { The place carries out } \\
\text { the function of regional } \\
\text { government with a } \\
\text { collective-pluralistic } \\
\text { pattern with the Niet } \\
\text { rechtstreek bestuure } \\
\text { gabied (State-Corpo- } \\
\text { ratism).. }\end{array}$ & $\begin{array}{l}\omega \text { The place of legal } \\
\text { subjects of rural } \\
\text { community with } \\
\text { territorial boundar- } \\
\text { ies. } \\
\omega \text { The place of tax ob- } \\
\text { jects and recruiting } \\
\text { soldiers for army. } \\
\omega \text { The place which } \\
\text { carry out regional } \\
\text { government func- } \\
\text { tions for the mobi- } \\
\text { lization of human } \\
\text { resources and a col- } \\
\text { lective-monolithic } \\
\text { nature with the Niet } \\
\text { rechtstreek bestu- } \\
\text { ure gabied (State- } \\
\text { Corporatism) sys- } \\
\text { tem. }\end{array}$ & $\begin{array}{l}\text { (1) The place of legal } \\
\text { subjects of rural } \\
\text { community with } \\
\text { autonomous terri- } \\
\text { torial boundaries. } \\
\omega \text { The place of } \\
\text { carrying out the } \\
\text { functions of the } \\
\text { regional govern- } \\
\text { ment is the low- } \\
\text { est, smallest, } \\
\text { intact part of the } \\
\text { regional govern- } \\
\text { ment system as } \\
\text { a village-small } \\
\text { town/regional } \\
\text { level III / Praja } \\
\text { Village with a } \\
\text { collective-plural- } \\
\text { istic environment } \\
\text { and a rechtstreek } \\
\text { bestuure gabied } \\
\text { system. }\end{array}$ & $\begin{array}{l}\omega \text { The place of } \\
\text { territorial area } \\
\text { where residents } \\
\text { live together as } \\
\text { legal subjects of } \\
\text { the rural com- } \\
\text { munity. } \\
\omega \text { The place of } \\
\text { central govern- } \\
\text { ment agen- } \\
\text { cies carry out } \\
\text { g o v e r m e } \mathrm{t} \\
\text { functions in de- } \\
\text { velopment that } \\
\text { are of a mono- } \\
\text { lithic-collective } \\
\text { pattern with the } \\
\text { Niet rechtstreek } \\
\text { bestuure gabied } \\
\text { (State-Corporat- } \\
\text { ism) system. }\end{array}$ & $\begin{array}{l}\omega \text { The place of legal subjects of } \\
\text { ordinary rural communities } \\
\text { and indigenous peoples who } \\
\text { have territorial boundaries. } \\
\omega \text { The place of artificial West- } \\
\text { ern-style democratization. } \\
\omega \text { The place which carries out } \\
\text { a monolithic governmen- } \\
\text { tal function with the Niet } \\
\text { rechtstreek bestuure gabied } \\
\text { (State-Corporatism) system. }\end{array}$ \\
\hline
\end{tabular}

The results of the analysis above must therefore be put back to the perspective of the theory which has taught the institutional arrangements for village governance that are 'Right and Good' which must be able to be associated with the principles of "Good Corporate Governance" and meets the "right" and "good" measures. True in the legal meaning constitutionally, and good in the legitimate meaning according to its usefulness (Assidiqi J, 2011) According to the provisions of the common law (Hans Kelsen in Assidiqi J.),(Assidiqi J, 2011) it confirms that the parameters of 'Syah' or legality are determined based on scientific principles or laws and regulations and 'Good' because they meet the conditions of benefit for the community. This matter must be observed in the arrangement of definition and meaning of village government institutions.

b. Positioning:

The institutional function of village government is to carry out the functions of government, but these functions are carried out outside the decentralized bureaucratic system of formal government, not also those that are symmetrical or asymmetrical. Therefore, the reality and the heavy burden of the functions borne by village government institutions ordered by Supra Village caused unrealistic imposition of these institutional functions to the rural community by selfgoverning, in which the real conditions of competence of the village government apparatus were low (Triputro, 2002) Determination of the institutional status of the village government outside the local government system in the form of a combined model of state corporatism system which is niet rechstreek bestuured gabied has a contra-productive impact on the performance of village government institutions. Positioning the institutional status of village government as statecorporatism is a deviation in the logic of local government administration that causes village government institutions to be mismanaged. The determination of the institutional status of the regional government is not a mechanism for the distribution of authority in the selected or not elected regional government system, therefore the village government institution is not a formal government unit in the area formed by the central government based on the principle of decentralization. 


\section{MATRIC-6 THE HISTORY OF INSTITUTIONAL ARRANGEMENTS ANALYSIS RESULTS ON VILLAGE GOVERNANCE AND ADMINISTRATION MODELS}

\begin{tabular}{|c|c|c|c|c|}
\hline \multirow{2}{*}{ No. } & \multirow{2}{*}{ Period of Legislation } & \multicolumn{3}{|c|}{ Conceptual and Theoretical Analysis } \\
\hline & & Administration Model & Juridical Implication & Politics of Law \\
\hline 1 & IGO 1906 jo. IGOB 1938 & $\begin{array}{l}\text { Legal entity community es- } \\
\text { tablished and controlled by the } \\
\text { State (Sate Corporatism) }\end{array}$ & $\begin{array}{ll}\checkmark & \begin{array}{l}\text { Niet rechtstreek bestuured } \\
\text { gabied }\end{array} \\
\checkmark & \text { State Corporatism }\end{array}$ & $\begin{array}{l}\checkmark \text { Kolonialisme_Niet oprecht over goed } \\
\text { bestuur }\end{array}$ \\
\hline 2 & $\begin{array}{l}\text { Osamu-Seirei No. } 27 \\
\text { Syoowa } 1942\end{array}$ & $\begin{array}{l}\text { Legal entity community es- } \\
\text { tablished and controlled by the } \\
\text { State (Sate Corporatism) }\end{array}$ & 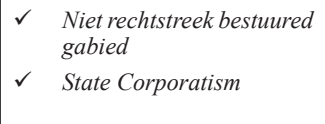 & $\begin{array}{l}\checkmark \text { Colonialism_Tight control of govern- } \\
\text { ment bureaucracy. } \\
\checkmark \text { HR Mobilization \& Exploitation of } \\
\text { Natural Resources for war. }\end{array}$ \\
\hline 3 & $\begin{array}{l}\text { Law Number } 1 \text { of } 1945 \\
\text { concerning Praja Village as } \\
\text { a Transitional Form to Ac- } \\
\text { celerate the Establishment } \\
\text { of Level III Regions in All } \\
\text { Regions of the Republic of } \\
\text { Indonesia }\end{array}$ & Modern Urban Decentralization & $\begin{array}{l}\text { Rechtstreek bestuured } \\
\text { gabied }\end{array}$ & $\begin{array}{ll}\checkmark & \text { Nationalism } \\
\checkmark & \text { Decentralism to good governance } \\
\checkmark & \text { Collectivisme Pluralistic }\end{array}$ \\
\hline 4 & $\begin{array}{l}\text { Law Number } 22 \text { of } 1948 \\
\text { concerning the Stipulation } \\
\text { of Basic Rules Regarding } \\
\text { Self-Government in Re- } \\
\text { gions That Have the Right } \\
\text { to Regulate and Manage } \\
\text { Their Own Households }\end{array}$ & Modern Urban Decentralization & $\begin{array}{l}\text { Rechtstreek bestuured } \\
\text { gabied }\end{array}$ & $\begin{array}{ll}\checkmark & \text { N Nationalism } \\
\checkmark & \text { Decentralism to good governance } \\
\checkmark & \text { Collectivisme Pluralistic }\end{array}$ \\
\hline 5 & $\begin{array}{l}\text { Law Number } 44 \text { of } 1950 \\
\text { concerning the State of } \\
\text { East Indonesia }\end{array}$ & Modern Urban Decentralization & $\begin{array}{l}\checkmark \quad \begin{array}{l}\text { Rechtstreek bestuured } \\
\text { gabied }\end{array} \\
\text { al }\end{array}$ & $\begin{array}{ll}\checkmark & \text { Nationalism } \\
\checkmark & \text { Decentralism to good governance } \\
\checkmark & \text { Collectivisme Pluralistic }\end{array}$ \\
\hline 6 & $\begin{array}{l}\text { Law Number } 1 \text { of } 1957 \\
\text { concerning the Principles } \\
\text { of Regional Government }\end{array}$ & Modern Urban Decentralization & $\begin{array}{l}\text { Rechtstreek bestuured } \\
\text { gabied }\end{array}$ & $\begin{array}{ll}\checkmark & \text { Nationalism } \\
\checkmark & \text { Decentralism to good governance } \\
\checkmark & \text { Collectivisme Pluralistic }\end{array}$ \\
\hline 7 & $\begin{array}{l}\text { Presidential Decree Num- } \\
\text { ber } 6 \text { of } 1959 \text { concerning } \\
\text { Regional Government }\end{array}$ & $\begin{array}{l}\text { Modern Urbaan Deconsentra- } \\
\text { tion }\end{array}$ & $\begin{array}{l}\checkmark \text { Rechtstreek bestuured } \\
\text { gabied }\end{array}$ & $\begin{array}{l}\checkmark \quad \text { Nationalism } \\
\checkmark \quad \text { Decentralism to good governance } \\
\checkmark \quad \text { Collectivisme Pluralistic }\end{array}$ \\
\hline 8 & $\begin{array}{l}\text { Law Number } 18 \text { of } 1965 \\
\text { concerning the Principles } \\
\text { of Regional Government }\end{array}$ & $\begin{array}{l}\text { Modern Urbaan Deconsentra- } \\
\text { tion }\end{array}$ & $\begin{array}{l}\checkmark \quad \text { Rechtstreek bestuured } \\
\text { gabied }\end{array}$ & $\begin{array}{l}\checkmark \quad \text { Nationalism } \\
\checkmark \quad \text { Decentralism to good governance } \\
\checkmark \quad \text { Collectivisme Pluralistic }\end{array}$ \\
\hline 9 & $\begin{array}{l}\text { Law Number } 19 \text { of } 1965 \\
\text { concerning Village Praja } \\
\text { As A Transitional Form } \\
\text { To Accelerate The Estab- } \\
\text { lishment Of Third Level } \\
\text { Regions In All Regions Of } \\
\text { The Republic Of Indonesia }\end{array}$ & Modern Urban Decentralization & $\begin{array}{l}\checkmark \text { Rechtstreek bestuured } \\
\text { gabied }\end{array}$ & $\begin{array}{ll}\checkmark & \text { Nationalism } \\
\checkmark & \text { Decentralism to good governance } \\
\checkmark & \text { Collectivisme Pluralistic }\end{array}$ \\
\hline 10 & $\begin{array}{l}\text { Law Number } 5 \text { of } 1979 \\
\text { concerning Village Go- } \\
\text { vernment }\end{array}$ & $\begin{array}{l}\text { Legal entity community es- } \\
\text { tablished and controlled by the } \\
\text { State (State Corporatism) }\end{array}$ & 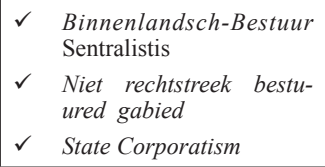 & $\begin{array}{ll}\checkmark & \text { Nationalism } \\
\checkmark & \text { Centralism to standard governance } \\
\checkmark & \text { Collectivisme Monolithic }\end{array}$ \\
\hline 11 & $\begin{array}{l}\text { Law Number } 22 \text { of } 1999 \\
\text { concerning Regional Gov- } \\
\text { ernment }\end{array}$ & $\begin{array}{l}\text { Legal entity community es- } \\
\text { tablished and controlled by the } \\
\text { State (State Corporatism) }\end{array}$ & $\begin{array}{ll}\checkmark & \text { Niet rechtstreek bestu- } \\
& \text { ured gabied } \\
\checkmark & \text { State Corporatism }\end{array}$ & $\begin{array}{l}\checkmark \quad \text { Nationalism } \\
\checkmark \quad \text { Quasi decentralism to good gover- } \\
\quad \text { nance } \\
\checkmark \quad \text { Collectivisme Pluralistic }\end{array}$ \\
\hline 12 & $\begin{array}{l}\text { Law Number } 32 \text { of } 2004 \\
\text { concerning Regional Gov- } \\
\text { ernment }\end{array}$ & $\begin{array}{l}\text { Legal entity community es- } \\
\text { tablished and controlled by the } \\
\text { State (State Corporatism) }\end{array}$ & $\begin{array}{ll}\checkmark & \text { Niet rechtstreek bestu- } \\
& \text { ured gabied } \\
\checkmark & \text { Local-State Government } \\
\checkmark & \text { State Corporatism }\end{array}$ & $\begin{array}{l}\checkmark \quad \text { Nationalism } \\
\checkmark \quad \text { Quasi decentralism to good gover- } \\
\quad \text { nance } \\
\checkmark \quad \text { Collectivisme Pluralistic }\end{array}$ \\
\hline 13 & $\begin{array}{l}\text { Law Number } 6 \text { of } 2014 \\
\text { concerning Villages }\end{array}$ & $\begin{array}{l}\text { Legal entity community es- } \\
\text { tablished and controlled by the } \\
\text { State (State Corporatism) }\end{array}$ & $\begin{array}{l}\checkmark \quad \begin{array}{l}\text { Local-self Government } \\
\text { \& Self-Governing Com- } \\
\text { munity }\end{array} \\
\checkmark \quad \begin{array}{l}\text { Niet rechtstreek bestu- } \\
\text { ured gabied }\end{array} \\
\checkmark \quad \text { State Corporatism }\end{array}$ & $\begin{array}{ll}\checkmark & \text { Nationalism } \\
\checkmark & \text { Quasi decentralism to good gover- } \\
& \text { nance } \\
\checkmark & \text { Collectivisme Pluralistic }\end{array}$ \\
\hline
\end{tabular}


In this Positioning issue, the policy makers in the village must pay attention to and refer to the Constitutional Court Decision, Decision Number 128/PUUXIII/2015 which essentially states that the institutional arrangements for village governance must be placed on the principles of the regional government system with the principle of decentralization, without overriding attributive authority based on recognition and subsidiarity.

c. Functioning:

The institutional function of village government is to carry out the functions of government, but these functions are carried out outside the decentralized bureaucratic system of formal government, not also those that are symmetrical or asymmetrical. Therefore, the large reality and the heavy burden of the functions borne by village government institutions ordered by Supra Village caused unrealistic imposition of these institutional functions to the rural community by self-governing, in which the real conditions of competence of the village government apparatus were low. Lawrence Mier Friedman theorizes that the effectiveness of the legal function of one of them depends on the merits of the legal structure, in addition to the legal substance and legal culture(Friedman L. M, 1993). The state enacted Law Number 6 of 2014 indeed with the intention to improve the welfare of the rural community. However, this village law functions outside the local government bureaucratic system called nietrechtstreek bestuured gabied (indirect government system). This unclear status is exacerbated by the system of governance of the combined model of local self-government and the self-governing community it adopts. Therefore, this village government institution is a perfect form of what is referred to as statecorporatism, as a socio-political organization regime formed by the State rather than as a government regime (Nurcholis. Hanif, 2018) It can be concluded that the institutional function of the village government is not solid as it does not follow the rules of the state administration law, both those 'in a state of silence' and those 'in a state of movement', as mandated by the 1945 Constitution of the Republic of Indonesia (Tutik T. T, 2012)

MATRIX-7 STRUCTURE AND INSTITUTIONAL FUNCTION OF VILLAGE GOVERNMENTS

\begin{tabular}{|c|c|c|c|c|c|}
\hline $\begin{array}{c}\text { The Head of } \\
\text { Village }\end{array}$ & $\begin{array}{c}\text { Village } \\
\text { Council } \\
\text { (BPD) }\end{array}$ & $\begin{array}{l}\text { Secretary } \\
\text { of Village } \\
\text { (Sekdes) }\end{array}$ & $\begin{array}{l}\text { Village Area } \\
\text { Executor } \\
\text { (PLK-Des/ } \\
\text { KAUR) }\end{array}$ & $\begin{array}{c}\text { Technique } \\
\text { Area Executor } \\
\text { (PLT-Des/ } \\
\text { KASI) }\end{array}$ & Orchard (Kadus) \\
\hline $\begin{array}{l}\text { 1. The Head of Vil- } \\
\text { lage is domiciled } \\
\text { as the Head of the } \\
\text { Village Govern- } \\
\text { ment who leads the } \\
\text { administration of } \\
\text { the Village Gov- } \\
\text { ernment.. }\end{array}$ & $\begin{array}{l}\text { 1. The village } \\
\text { government } \\
\text { body is an in- } \\
\text { stitution whose } \\
\text { members are } \\
\text { representatives } \\
\text { of the villagers } \\
\text { who are demo- } \\
\text { cratically deter- } \\
\text { mined based on } \\
\text { the territory. }\end{array}$ & $\begin{array}{l}\text { 1. The Secretary of } \\
\text { Village is located } \\
\text { as an element of } \\
\text { the leadership of } \\
\text { the Secretary of } \\
\text { Village }\end{array}$ & $\begin{array}{l}\text { 1. Head of Affairs } \\
\text { shall be an ele- } \\
\text { ment of the secre- } \\
\text { tariat staff. }\end{array}$ & $\begin{array}{l}\text { 1. The Section Head } \\
\text { is located as an el- } \\
\text { ement of technical } \\
\text { executor }\end{array}$ & $\begin{array}{l}\text { 1. The Head of the Territorial } \\
\text { Area, called the Orchard or } \\
\text { other designation, is posi- } \\
\text { tioned as an element of the } \\
\text { regional task force tasked } \\
\text { with assisting the Village } \\
\text { Head in carrying out his du- } \\
\text { ties in his area. }\end{array}$ \\
\hline
\end{tabular}




\begin{tabular}{|c|c|c|c|c|c|}
\hline $\begin{array}{l}\text { 2. The village head is } \\
\text { in charge of orga- } \\
\text { nizing village gov- } \\
\text { ernance, carrying } \\
\text { out development } \\
\text { and community } \\
\text { empowerment. }\end{array}$ & $\begin{array}{l}\text { 2. The function of } \\
\text { the BPD is the } \\
\text { planning \& su- } \\
\text { pervision of the } \\
\text { development } \\
\text { process }\end{array}$ & $\begin{array}{l}\text { 2. The Secretary of } \\
\text { Village is tasked } \\
\text { with assisting the } \\
\text { Village Head in } \\
\text { the field of gov- } \\
\text { ernment adminis- } \\
\text { tration. }\end{array}$ & $\begin{array}{l}\text { 2. The Head of Af- } \\
\text { fairs is tasked with } \\
\text { assisting the Sec- } \\
\text { retary of Village } \\
\text { in matters of sup- } \\
\text { porting }\end{array}$ & $\begin{array}{l}\text { 2. The Head of the } \\
\text { section assists the } \\
\text { head of village as } \\
\text { an operational task } \\
\text { executor. }\end{array}$ & $\begin{array}{l}\text { 2. To perform the job of Or- } \\
\text { chard or other designations } \\
\text { have the function: }\end{array}$ \\
\hline $\begin{array}{l}\text { 3. To carry out its } \\
\text { duties the Village } \\
\text { Head has the fol- } \\
\text { lowing functions: }\end{array}$ & $\begin{array}{l}\text { 3. To discuss and } \\
\text { agree on the } \\
\text { village regula- } \\
\text { tion plan with } \\
\text { the village head }\end{array}$ & $\begin{array}{l}\text { 4. The Secretary of } \\
\text { Village is tasked } \\
\text { with assisting the } \\
\text { Village Head in } \\
\text { the field of gov- } \\
\text { ernment adminis- } \\
\text { tration. }\end{array}$ & $\begin{array}{l}\text { 3. To carry out its } \\
\text { duties the Head of } \\
\text { Affairs has the fol- } \\
\text { lowing functions: }\end{array}$ & $\begin{array}{l}\text { 1. To carry out his } \\
\text { duties the section } \\
\text { head has the func- } \\
\text { tion: }\end{array}$ & $\begin{array}{l}\text { 3. Fostering peace and order, } \\
\text { implementation of com- } \\
\text { munity protection efforts, } \\
\text { population mobility, and } \\
\text { regional arrangement and } \\
\text { management; }\end{array}$ \\
\hline $\begin{array}{l}\text { 4. Organizing village } \\
\text { governance, such } \\
\text { as governance of } \\
\text { the government, } \\
\text { establishing regu- } \\
\text { lations in the vil- } \\
\text { lage, fostering land } \\
\text { issues, fostering } \\
\text { peace and order, } \\
\text { carrying out efforts } \\
\text { to protect the com- } \\
\text { munity, population } \\
\text { administration, and } \\
\text { spatial planning } \\
\text { and management }\end{array}$ & $\begin{array}{l}\text { 4. Accommodat- } \\
\text { ing and chan- } \\
\text { neling the } \\
\text { aspirations of } \\
\text { the community, } \\
\text { and oversee- } \\
\text { ing the perfor- } \\
\text { mance village } \\
\text { head. }\end{array}$ & $\begin{array}{l}\text { 4. To carry out its } \\
\text { duties the Sec- } \\
\text { retary of Village } \\
\text { has the following } \\
\text { functions: }\end{array}$ & $\begin{array}{l}\text { 4. The Head of Ad- } \\
\text { ministrative and } \\
\text { General Affairs } \\
\text { has functions } \\
\text { such as carrying } \\
\text { out administra- } \\
\text { tive matters such } \\
\text { as manuscripts, } \\
\text { administration of } \\
\text { correspondence, } \\
\text { archives, and ex- } \\
\text { peditions, and } \\
\text { administrative ar- } \\
\text { rangement of vil- } \\
\text { lage apparatuses, } \\
\text { provision of vil- } \\
\text { lage apparatus } \\
\text { and office infra- } \\
\text { structure, meeting } \\
\text { preparation, asset } \\
\text { administration, } \\
\text { inventory, official } \\
\text { travel and public } \\
\text { services. }\end{array}$ & 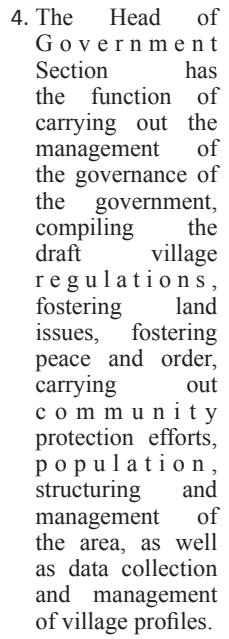 & $\begin{array}{l}\text { 4. Supervise the implementa- } \\
\text { tion of development in the } \\
\text { area; }\end{array}$ \\
\hline $\begin{array}{l}\text { 5. carry out develop- } \\
\text { ment, such as con- } \\
\text { struction of rural } \\
\text { infrastructure, and } \\
\text { development of } \\
\text { education, health }\end{array}$ & & $\begin{array}{l}\text { 5. Carry out ad- } \\
\text { min is trati ve } \\
\text { matters such as } \\
\text { manuscripts, ad- } \\
\text { ministration of } \\
\text { correspondence, } \\
\text { archives, and ex- } \\
\text { peditions; }\end{array}$ & $\begin{array}{l}\text { 5. The Head of Fi- } \\
\text { nancial Affairs } \\
\text { has functions } \\
\text { such as carrying } \\
\text { out financial af- } \\
\text { fairs such as the } \\
\text { administration of } \\
\text { financial adminis- } \\
\text { tration, adminis- } \\
\text { tration of income } \\
\text { and expenditure } \\
\text { sources, verifica- } \\
\text { tion of financial } \\
\text { administration, } \\
\text { and income ad- } \\
\text { ministration of } \\
\text { the Village Head, } \\
\text { Village Appa- } \\
\text { ratus, BPD, and } \\
\text { other village gov- } \\
\text { ernment institu- } \\
\text { tions. }\end{array}$ & $\begin{array}{l}\text { 5. The Head of the } \\
\text { Welfare Section } \\
\text { has the function } \\
\text { of carrying out } \\
\text { the construction } \\
\text { of rural infra- } \\
\text { structure, devel- } \\
\text { opment of educa- } \\
\text { tion, health, and } \\
\text { socialization tasks } \\
\text { as well as com- } \\
\text { munity motiva- } \\
\text { tion in the fields } \\
\text { of culture, econ- } \\
\text { omy, politics, en- } \\
\text { vironment, fam- } \\
\text { ily empowerment, } \\
\text { youth, sports, and } \\
\text { youth. }\end{array}$ & $\begin{array}{l}\text { 5. Carry out community de- } \\
\text { velopment in increasing the } \\
\text { ability and awareness of the } \\
\text { community in protecting } \\
\text { their environment; }\end{array}$ \\
\hline $\begin{array}{l}\text { 6. Community deve- } \\
\text { lopment, such as } \\
\text { the implementa- } \\
\text { tion of community } \\
\text { rights and obliga- } \\
\text { tions, community } \\
\text { participation, com- } \\
\text { munity socio-cul- } \\
\text { tural, religious, and } \\
\text { manpower }\end{array}$ & & $\begin{array}{l}\text { 6. Carry out pub- } \\
\text { lic affairs such } \\
\text { as structuring } \\
\text { administration } \\
\text { of village appa- } \\
\text { ratus, provision } \\
\text { of village and } \\
\text { office equipment } \\
\text { infrastructure, } \\
\text { preparation of } \\
\text { meetings, admin- } \\
\text { istration of assets, } \\
\text { inventory, travel } \\
\text { dinas, and public } \\
\text { services }\end{array}$ & $\begin{array}{l}\text { 6. The Head of } \\
\text { Planning Affairs } \\
\text { has the function } \\
\text { of coordinating } \\
\text { planning matters } \\
\text { such as compiling } \\
\text { village income } \\
\text { and expenditure } \\
\text { budget plans, in- } \\
\text { ventorying data in } \\
\text { the context of de- } \\
\text { velopment, moni- } \\
\text { toring and evalu- } \\
\text { ating programs, } \\
\text { and preparing } \\
\text { reports. }\end{array}$ & $\begin{array}{l}\text { 6. The Head of the } \\
\text { Service Section } \\
\text { has the func- } \\
\text { tion of carrying } \\
\text { out counseling } \\
\text { and motivation } \\
\text { towards the im- } \\
\text { plementation of } \\
\text { community rights } \\
\text { and obligations, } \\
\text { increasing ef- } \\
\text { forts of commu- } \\
\text { nity participation, } \\
\text { preservation of } \\
\text { social, cultural, } \\
\text { religious, and } \\
\text { manpower values. }\end{array}$ & $\begin{array}{l}\text { 6. Make efforts to empower the } \\
\text { community in supporting the } \\
\text { smooth running of govern- } \\
\text { ment and development. }\end{array}$ \\
\hline
\end{tabular}




\begin{tabular}{|c|c|c|c|c|}
\hline $\begin{array}{l}\text { 7. C o m m u n i t y } \\
\text { empowerment, } \\
\text { such as the task } \\
\text { of socialization } \\
\text { and community } \\
\text { motivation in the } \\
\text { fields of culture, } \\
\text { economy, politics, } \\
\text { environment, fam- } \\
\text { ily empowerment, } \\
\text { youth, sports, and } \\
\text { youth organiza- } \\
\text { tions. }\end{array}$ & $\begin{array}{l}\text { 7. Carry out finan- } \\
\text { cial affairs such } \\
\text { as the administra- } \\
\text { tion of financial } \\
\text { administration, } \\
\text { administration } \\
\text { of income and } \\
\text { ex p e n d it u r e } \\
\text { sources, verifica- } \\
\text { tion of financial } \\
\text { administration, } \\
\text { and income ad- } \\
\text { ministration of } \\
\text { the Village Head, } \\
\text { Village Officials, } \\
\text { BPD, and other } \\
\text { village govern- } \\
\text { ment institutions }\end{array}$ & $\begin{array}{l}\text { 7. The Head of Gen- } \\
\text { eral Affairs and } \\
\text { Planning has func- } \\
\text { tions such as car- } \\
\text { rying out affairs } \\
\text { admin is tration } \\
\text { such as manu- } \\
\text { scripts, correspon- } \\
\text { dence adminis- } \\
\text { tration, archives } \\
\text { and expeditions, } \\
\text { administration of } \\
\text { village appara- } \\
\text { tuses, provision of } \\
\text { village and office } \\
\text { equipment infra- } \\
\text { structure, prepara- } \\
\text { tion of meetings, } \\
\text { administration of } \\
\text { assets, inventory, } \\
\text { official travel, } \\
\text { public services, } \\
\text { coordinating plan- } \\
\text { ning affairs such } \\
\text { as preparing vil- } \\
\text { lage revenue and } \\
\text { expenditure bud- } \\
\text { get plans, inven- } \\
\text { torying data in the } \\
\text { framework of de- } \\
\text { velopment, moni- } \\
\text { toring and evaluat- } \\
\text { ing programs, and } \\
\text { preparing reports. }\end{array}$ & $\begin{array}{l}\text { 7. The Head of the } \\
\text { Welfare and Ser- } \\
\text { vice Section has } \\
\text { the function of } \\
\text { carrying out the } \\
\text { construction of ru- } \\
\text { ral infrastructure, } \\
\text { development of } \\
\text { education, health, } \\
\text { and socialization } \\
\text { tasks as well as } \\
\text { community moti- } \\
\text { vation in the fields } \\
\text { of culture, eco- } \\
\text { nomics, politics, } \\
\text { environment, fam- } \\
\text { ily empowerment, } \\
\text { youth, sports, } \\
\text { youth, implement- } \\
\text { ing counseling and } \\
\text { motivation for the } \\
\text { implementation } \\
\text { of community } \\
\text { rights and obliga- } \\
\text { tions, increasing } \\
\text { efforts for com- } \\
\text { munity participa- } \\
\text { tion, preservation } \\
\text { of social, cultural, } \\
\text { religious, and em- } \\
\text { ployment values. }\end{array}$ & \\
\hline $\begin{array}{l}\text { 8. Maintain partner- } \\
\text { ship relations with } \\
\text { community insti- } \\
\text { tutions and other } \\
\text { institutions }\end{array}$ & $\begin{array}{l}\text { d. Carry out plan- } \\
\text { ning matters } \\
\text { such as preparing } \\
\text { village income } \\
\text { and expenditure } \\
\text { budget plans, in- } \\
\text { ventorying data } \\
\text { in the framework } \\
\text { of development, } \\
\text { monitoring and } \\
\text { evaluating pro- } \\
\text { grams, and pre- } \\
\text { paring reports. }\end{array}$ & & & \\
\hline $\begin{array}{l}\text { e. Other duties in ac- } \\
\text { cordance with sta- } \\
\text { tutory regulations. }\end{array}$ & & & & \\
\hline
\end{tabular}

d. Authorizing:

The authority over the attributive authority that Supra Village has bestowed upon village government institutions through the Recognition and Subsidiarity principle is completely outside the principle of decentralization. This situation causes the village government institutions to not be fully a full government institution in the bureaucratic system of the Republic of Indonesia government, and do not have complete technical and resource functions in carrying out their functions. Whereas, in the state administration law, the issue of 'authority' is fundamental to the division of authority in order to realize the achievement of public goals as a form of the state in a movement state (Hoessein, 2011). Thus, the Village Government with its authority is not exercising authority as a local stategovernment nor is it local self-government. Therefore, the village government institutions do not exercise the authority of central government policies nor do they regulate and manage decentralized government affairs (Gaffar K. A. (ed), 2003) 
e. Actuating (Tasking-Activating):

Real conditions are too large and the complexity of the assignment of services, development, empowerment and development of village communities that are charged to village government institutions, as well as the lack of solid work tools for village government apparatuses are still minimal, indicating poor regulatory norms in Government Regulation Number 43/2014 Jo Government Regulation 47/2015 is technocratic in nature with village government institutions. The Government Regulation is overestimating in the matter of building village government institutional technocracy, as for it does not meet the criteria and principles in the formation of legislation (Law Number 12 of 2011), particularly the principle of Het Beginsel van de Individuele Rechbedeling (individual employee capacity) and Het Beginsel van Duidelijke Doelstelling (achievement purpose). Thus, the problem is whether the village government institution in its implementation has fulfilled the principles of the organ/the right institution/beginsel van het juiste organ; the principle can be implemented/ het beginsel van uitvoerbaarheid; correct terminology and systematic principles/ het beginsel van duidelijke terminologi en duidelijke systemetiek (Vlies, 1987).

f. Controlling:

The construction of a village government institutional supervision system is based on Law Number 23 of 2014 Regarding Regional Government Jo. Law Number 9 of 2015 concerning the second amendment to the Regional Government Law, in terms of the relationship between the village government and the central government (the State), the existence of village government institutions is placed as a quasi-government in the regency / city area in carrying out government affairs. The supervisory function carried out by the BPD towards the Village Government appears to be ineffective, due to the weak competence of the apparatus. Supervision through the role of community participation is still very low due to the lack of democratic climate, as an impact, community involvement in the process of village policy making is still very weak.

\section{Conclusion}

The disharmony of village governance institutional arrangements is due to the regulations are not derived from the proper and good institutional governance of village governance that should refer to the local government regime. Ratio legis, philosophically forming Law Number 6 of 2014, which is a Localist-Exististism, rather than ModernistOrientalism or Exsistentialism-Orientalism by placing the definition of village government institutions outside the local government system/autonomous regions. Juridically, village government institutions are assumed to be historical facts as the lowest autonomous government, therefore, attributive authority is based on the principles of recognition and subsidiarity outside the local government system. Theoretically, the institutional formation platform for village governance is based on the assumption of a joint model of local-self-government system with self-governing community as villagehybrid. However, all articles of Law Number 6 of 2014 regulates the structure, authority, functions, tasks and work mechanism of the Village and Customary Villages as a semi- 
autonomous government bureaucratic organization, not regulating Customary Villages and Villages as self governing communities and Customary Villages and Villages as autonomous local government (local self-government).

The disharmony implication shows that Law Number 6 of 2014 does not clarify the rights and authority of villages and even worsen the governance system in Indonesia, both from the perspective of meaning, positioning, functioning, authorizing, actuating, and controlling. Ius-constituendum, legally, the institutional authority of village government must be placed within the formal LG system; theoretically the institutional platform for village governance as a village-hybrid must be derived from a proper and good LG governance system. Learning from the experience of the institutional history of village governance, the norms of Law Number 6 of 2014 need to be improved and derived from a good and right local governance system, and must be harmonized vertically with the 1945 Constitution, and horizontally with Law Number 5 of 2014 on Apparatus State Civil and Law Number 17 of 2003 on State Finances; For the future reconstruction of a strategic system of village governance, it is necessary to develop a platform of general principles of good governance and open access to community participation through democratization of the village in creating conducive conditions for supervision between the Village Head, BPD and the community themselves;

Going forward, to ensure the creation of an orderly administration law for regional government, the institutions of ordinary/formal/official/bureaucratic and villagelevel village government and traditional villages need to be thoroughly studied and classified into three categories: 1) as a living traditional community; 2) as indigenous people who have difficulty surviving only fade away so that their habits can be revived; 3) as indigenous people who really die that their habits no longer exist in the community(Constitution of the Republic of Indonesia 1945, n.d.) With regard to the first category, the Government must be responsive to recognize and respect their existence. With regard to the second category, the Government must revitalize them to preserve customary law can be revived to be recognized and respected. With regard to the third category, the Government must make two policies: 1) urban/modern villages must be included in the current administration system of the regional government, which is part of the district/city government as a symmetrical autonomous village (Ordinary/ Formal/Bureaucratic/Official Village); and 2) villages that have rural characteristics are combined with each other into an customary-based autonomous region as an asymmetric regional government (Article 18 B Paragraph (1) Jo. Paragraph (7) of the 1945 Constitution of the Republic of Indonesia and Decree of the Indonesian People's Assembly (MPR) Number IV/2000). Therefore, all village government institutions are no longer placed as niet rechstreek bestuured gabied.

\section{BIBLIOGRAPHY}

\section{Books:}

Assidiqi J. (2011). Oration in the context of Silaturrahim Board of the Indonesian Da'wah Council (DDII). 
Friedman L. M. (1993). Teori dan Filsafat hukum: Telaah kritis atasi Teori-Teori Hukum. Jakarta: PT Raja Grafindo Persada.

Gaffar K. A. (ed). (2003). Kompleksitas Persoalan Otonomi Daerah di Indonesia. Yogyakarta: Student Library and Government of the Faculty of Social Sciences UGM.

Hadjon P. M. (2005). Pengantar Hukum Administrasi Indonesia. Yogyakarta: Gadjah Mada University Press.

Hoessein, B. (2011). Perubahan Model, Pola, dan Bentuk Pemerintaha Daerah dari Era Orde Baru ke Era Reformasi. Depok: DIA FISIP UI.

Nurcholis. Hanif. (2018). Village Government. Artificial and Unconstitutional Government Units. Paper presented in the book review "Village Government: Unofficial Government Units in the State Union of Republic of Indonesia, Government System." Jakarta: Bee Media Indonesia Publisher.

Pusat Bahasa Kemdikbud. (2016). Kamus Besar Bahasa Indonesia (KBBI). Kementerian Pendidikan Dan Budaya.

Soetardjo Kartohadikoesoemo. (1984). Desa. Jakarta: Balai Pustaka.

Strong C. F. (2015). Modern Political Constitutions. Modern Political Constitutions. Comparative Study of History and Form. Bandung: Nusa Media Publisher.

Sudarsono. (2019). Hukum Administrasi Negara _ Konsep MPFAAC: Meaning - Positioning Functioning - Authorizing - Actuating - Controlling. Malang: Universitas Brawijaya Press.

Team, D. D. (1989). Language Development and Coaching Center, Large Indonesian Dictionary. Jakarta: Balai Pustaka.

Triputro, R. W. (2002). Reposisi Birokrasi Pemerintah Desa. Jurnal Ilmu Sosial Alternatif. Yogyakarta: Sekolah Tinggi Pembangunan Masyarakat Desa.

Tutik T. T. (2012). Pengantar Hukum Tata Usaha Negara. Jakarta: Prestasi Pustaka Publisher.

Vlies, I. C. Van de. (1987). Handboek Wetgeving. , Zwolle: Tjeenk Willink.

\section{Journals/Proceding/Articles:}

Carr, D., Echols, J. M., \& Shadily, H. (1977). An English-Indonesian Dictionary. Journal of the American Oriental Society. https:// doi.org/10.2307/599041

Dyzenhaus, D. (2012). Legality and LegitimacyCarl Schmitt, Hans Kelsen, and Hermann Heller in Weimar. In Legality and LegitimacyCarl Schmitt, Hans Kelsen, and Hermann Heller in Weimar. https:/ / doi.org/10.1093/acprof:oso/9780198298465.001.0001

Israwan S. P. (2011). Akuntabilitas Administrasi Keuangan Program Alokasi Dana Desa (ADD), on Jurnal Ilmu Administrasi Negara. Jurnal Ilmu Administrasi Negara, 11(1), 25.

Kukuh Tejomurti. (2018). Memberdayakan Koperasi Sampah Berbasis Otonomi Desa Dalam Mewujudkan Desaa Ramah Lingkungan dan Berkelanjutan. Jurnal Law Review Volume XVII, Number 3. Universitas Pelita Harapan 
Roper, D. M., \& Friedman, L. M. (1976). The Legal System: A Social Science Perspective. Political Science Quarterly. https:/ / doi.org/10.2307/2148447

Veen, T. (1993). Cornelis Van Vollenhoven Over Onze Nationale Staatsrechtsstudie. Legal History Review. https:/ / doi.org/10.1163/157181993X00259

\section{Legal Documents:}

Inlandsche Statregeling 1854.

Inlandsche Gemeente Ordonantie 1906.

Inlandsche Gemeente Ordonantie Buitengewesten 1938.

Desa Ordonnantie 1941.

Osamu Seirei No. 27/1942

Osamu Seirei No. 7/1944

The 1945 Constitution (Before Amendments).

Statue of The People's Consultative Assembly Number IV of 2000 on Policy Recommendations in the Implementation of Regional Autonomy.

Law Number 22 of 1948 on the Establishment of Basic Rules Regarding Self-Government in Regions That Have the Right to Regulate and Manage Their Own Households.

Law Number 1 of 1957 on the Principles of Regional Government Presidential Decree Number 6 of 1959 on Local Government.

Law Number 18 of 1965 on the Principles of Regional Government Law Number 19 of 1965 concerning Praja Village

Law Number 6 of 1966 on Statements of Non-Applicability of Various Laws and Government Regulations in Lieu of Laws

Law Number 5 of 1974 on Principles of Government in the Regions

Law Number 5 of 1979 on Village Government.

Law Number 22 of 1999 on Local Government.

Law Number 32 of 2004 on Local Government.

Government Regulation Number 72 of 2005 on Villages.

Statue of The People's Consultative Assembly Number IV of 2000 on Policy Recommendations in the Implementation of Regional Autonomy.

Decision of the Constitutional Court Number 31/PUU-V/2007.

Government Regulation Number 72 of 2005 concerning Villages. Decision of the Constitutional Court Number 31/PUU-V/2007.

Contitutional Court. (2015). Decision of the Constitutional Court Number 128/PUU RIXIII/2015.

\section{Websites:}

www.bustingbureaucracy.com

http://www.swaberita.com/2008/05/29/nusantara/suku-baduy-di-pedalamanbanten.html

http:/ / wikipedia.com

Webb Site, Forum Pengembangan Pembaharuan Desa www.forumdesa.org 2007-2017. 